\title{
Payments for Ecosystem Services Incentives and Adoption of Land Use Interventions in Uluguru Mountains, Tanzania
}

\author{
Lazaro Kagata ${ }^{\text {* }}$, Felister Mombo ${ }^{2}$, Fatihiya A. Massawe ${ }^{3}$ \\ ${ }^{1}$ Sokoine University of Agriculture, Morogoro, Tanzania \\ ${ }^{2}$ Department of Forest \& Environmental Economics, College of Forest, Wildlife \& Tourism, \\ Sokoine University of Agriculture, Morogoro, Tanzania \\ ${ }^{3}$ Department of Policy, Planning and Management, College of Social Sciences and Humanities, \\ Sokoine University of Agriculture, Morogoro, Tanzania \\ Email: ^lazakagata@gmail.com, ^lazaro.kagata@yahoo.com, fmombo@yahoo.com,mnkya74@gmail.com
}

How to cite this paper: Kagata, L., Mombo, F. and Massawe, F.A. (2018) Payments for Ecosystem Services Incentives and Adoption of Land Use Interventions in Uluguru Mountains, Tanzania. Agricultural Sciences, 9, 299-316.

https://doi.org/10.4236/as.2018.93022

Received: January 25, 2018

Accepted: March 20, 2018

Published: March 23, 2018

Copyright (c) 2018 by authors and Scientific Research Publishing Inc. This work is licensed under the Creative Commons Attribution International License (CC BY 4.0).

http://creativecommons.org/licenses/by/4.0/

\begin{abstract}
The role played by Payments for ecosystem services (PES) in promoting land use interventions is increasingly being recognized as an important instrument for changing land use management worldwide. Despite the increase, adoption of land use interventions promoted by PES and factors influencing it are not well understood. This study was carried out to assess the adoption of land use interventions promoted by PES scheme four years after its implementation in the Uluguru Mountains, Tanzania. The specific objectives of this study were to assess the adoption and factors that influenced it. The study employed questionnaire survey method to collect data from 219 households selected randomly. Focus group discussions and key informant interviews were also conducted to complement information obtained through questionnaire surveys. Descriptive and inferential statistical analyses were employed. Binary logistic regression was used to analyse quantitative data obtained, while content analysis was applied to qualitative data. Results revealed that during the project implementation, $40 \%$ of the households did not adopt any of the promoted interventions. Unexpectedly, four years after the project ended, every household sampled had adopted the interventions. Households headed by younger heads and those with land ownership, households which received PES incentives and lived for a long time in the same area and those with more labour force and access to extension services were found to have adopted more interventions $(\mathrm{p} \leq 0.05)$. Thus, the study concludes that socioeconomic characteristics, agricultural extension services and incentives initially provided to farmers are key factors influencing the adoption of land use interventions. Therefore, it is recommended to the government that it should support far-
\end{abstract}


mers to get land tenure and to provide them with more incentives to improve their farms through adopting technologies.

\section{Keywords}

Ecosystem Services, Payments for Ecosystem Services, Watersheds, Land Use Interventions, Incentives and Adoption

\section{Introduction}

Ecosystems play an important role necessary for supporting living and non-living things in provision of different services such as food, water and climate regulation [1] [2]. However, apart from different initiatives such as state control and participatory management taken by different countries to manage ecosystems for them to continue to provide Ecosystem Services (ES) sustainably, land degradation is vivid [3]. It is in this direction that led to the emergence of Participatory Management which had a varying degree of local community involvement. But, out of its expectation participatory management of ecosystems, which was thought, would relieve the ecosystems from degradation, it ends up with little hopes in reducing land degradation challenges failed to bringing some of the decayed ecosystems back to their required status to sustainably provide the ES. The biggest challenge to participatory management approach was lack of incentives for the participating communities [4] [5]. Hence payment for ecosystem services (PES) was developed as a strategy to enhance the sustainable ecosystem management in both developed and developing countries by providing incentives to the ecosystem producers particularly rural farmers.

Provision of incentive is evident in the study by [6] and [7] PES play important roles by helping to reduce costs for producers of ecosystem services particularly to farmers by providing incentives, mainly financial and technical support, which lead to a great challenge to participatory management approach. The referred above authors argue that PES has, from the last two decades, become a mainstream environmental policy. The strategy has also started to be used to reforest or to restore degraded ecosystems such as watersheds, sequester carbon through maintaining vegetation cover and preserving biodiversity [8]. In Watershed areas, the instrument is used as conservation practices that enhance natural supply of fresh water. The flows are highly influenced by land use practices, particularly those which are conducted to the upstream. The impacts are very much felt by downstream land users [2] including quality and quantity of water flows. Such watersheds degradation resulting from upstream human practices is frequently observed in many developing countries despite various initiatives taken to conserve them [4]. As a result, many developing countries are facing water flows scarcity, and whatever amount flows is of low quality [9].

In Tanzania, PES schemes were introduced in different areas which include 
watersheds management in Uluguru Mountains in 2006 where degradation of watersheds was reported to be high [10]. A similar PES scheme was implemented to conserve wildlife in Simanjiro, Northern Tanzania and for forest reduction in the Kilombero, Morogoro and wetlands catchment area. However, apart from its importance, PES schemes in developing countries including Tanzania faced significant challenges from the beneficiaries due to the fact that some had have no clear direction on whether to adopt new technologies. This scenario was the result of various reasons which include weak institutions, missing markets, high incidence of poverty and insecure land tenure [8] [11] [12] [13] [14]. Despite all these challenges, yet scholars believe that if PES is appropriately designed, it can be helpful to sustainably manage land and water resources at the same time contribute to poverty alleviation of rural communities through farming [15].

PES scheme under the equitable payment for watersheds services (EPWS) project was introduced by the Cooperative for Assistance and Relief Everywhere (CARE) International and World Wildlife Fund (WWF) NGOs in uluguru mountains, Tanzania [10]. The major objective of the project was to influence farmers to adopt land use interventions namely bench terraces, reforestation, agro-forestry and grass stripping farming for the purpose of enhancement of ecosystems and improvement of crop productivity whereby farmers were promised to receive incentives among other things included financial support, bush knives, goats, spades, hoes, trees, crop seedlings and manure. As [16] highlighted the project aimed at improving the welfare of the rural people as well as watersheds management through sustainable farming practices named earlier. Thus, understanding to whether farmers in the study area adopted the promoted land use interventions and the factors which influenced them was crucial important.

A study by [17] in Uluguru Mountains shows that during the early stages of the PES scheme implementation about $50 \%$ of farmers adopted the promoted interventions. However, the adoption four years after the project and factors influencing the adoption were not well understood. This study aimed, therefore, to assess the PES incentives and adoption of the promoted interventions four years after the project in the Uluguru Mountains, Tanzania. The specific objectives of the study were to investigate the adoption and factors influencing it in order to add knowledge into empirical literature and also inform policy makers and other stakeholders on the use of PES scheme in attracting rural farmers to adopt sustainable agricultural practices.

\section{Theoretical Framework}

This study draws on the theory of diffusion of innovations by [18] to show how farmers make decision to adopt or not adopt an innovation. Diffusion refers to the process by which innovations are spread among the members of a social system over time. An innovation can be an idea or concept, technical information or an actual practice that is perceived as new by the individual. According to 
[19] there are five identified characteristics that determine the adoption of an innovation namely the relative advantage, compatibility, complexity, trialability and observability. The decision to adopt an innovation is a mental process consisting of five stages: knowledge, persuasion, decision, implementation and confirmation. The innovativeness of an individual determines when the individual adopts the innovation and recognized five successive adopter categories: innovators, early adopters, early majority, late majority and laggards [19]. The assumption of diffusion theory is that adoption process is also affected farmers characteristics, such as personality, social characteristics and the perceived need for the innovation. Though scholars like [20] view diffusion theory as a simplified complex representation yet, the theory is commonly used to study farmers' probability of adopting or not adopting new technologies [21]. Thus, in this study, the theory' side as were used to assess farmers' adoption of the land use interventions whereby the characteristics of the land use interventions may make some farmers reject or adopt them. In this study adoption means implementing at least one of the proposed interventions which included bench terraces, agro-forestry, reforestation and grass strip farming.

\section{Conceptual Framework}

The conceptual framework (Figure 1) for this study is built on the diffusion theory's assumptions that for the farmers to make decisions of either adopting or not depends on other factors imbedded in the theory as well as targeted community. It therefore expands on these factors to explain the relationships between innovation of PES initiatives, institutional factors and household characteristics in the case of ecosystems management. These three factors are critical variables that determine adoption decision that has an impact on the ecosystem. Furthermore, the adoption factors inform policy makers on how PES initiatives work in raising adoption decision, and how the institution factors and households characteristics influence such decision to occur.

Variables in the conceptual framework as indicated in Table 1 among others were entered into the binary logistic regression model for analysis to explore factors that influenced adoption of the promoted interventions. Furthermore, in this study, the results of past studies on farmers' adoption of innovation, the existing theoretical explanations and the researcher's knowledge of the farming systems at the study area were used to select explanatory variables.

\section{Methodology}

\subsection{The Study Area}

The study area was at Kibungo Juu ward, in the Uluguru Mountains which are part of the Eastern Arc Mountain Forests and also they form part of the ten most important tropical forest areas for conservation in Africa [22]. Kibungo Juu Ward is located about $85 \mathrm{~km}$ South-East of Morogoro town. This Ward is found in Morogoro Rural District, Morogoro Region, about $200 \mathrm{~km}$ west of Dar es 


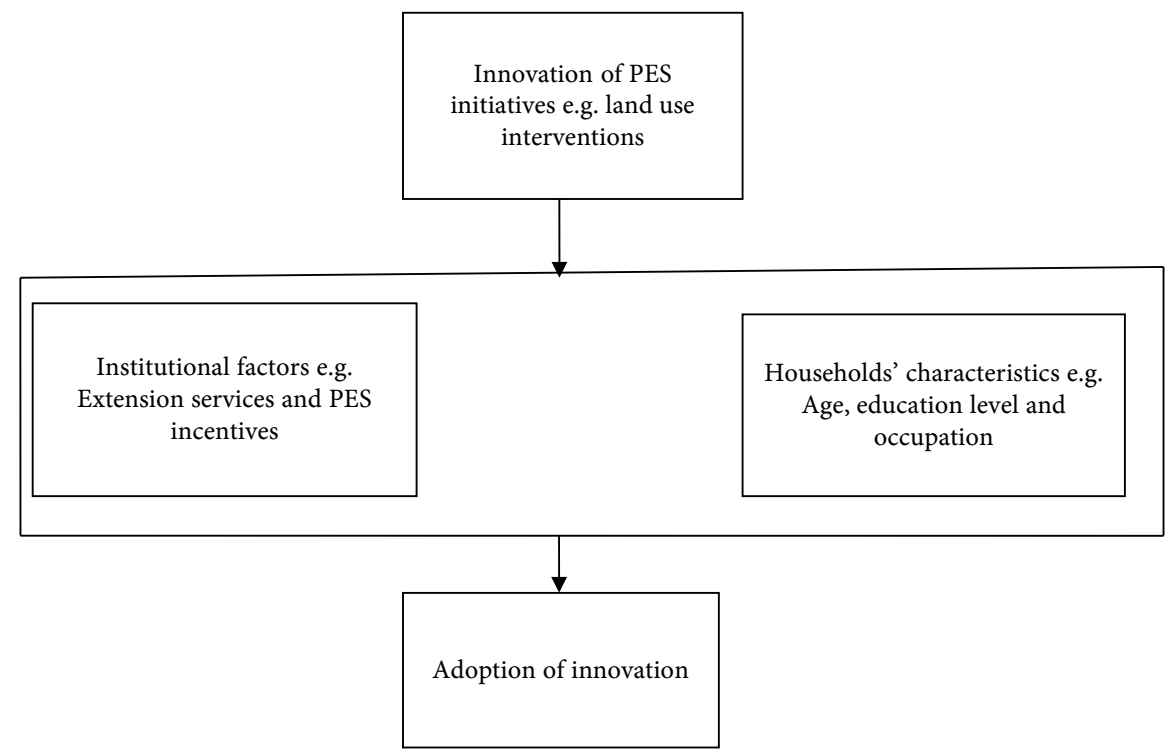

Figure 1. Conceptual framework. Source: Author's construct (2017).

Table 1. Variables in the conceptual framework.

\begin{tabular}{|c|c|c|}
\hline Variable & Definition & Measurement \\
\hline $\begin{array}{l}\text { Adoption of } \\
\text { innovation }\end{array}$ & $\begin{array}{l}\text { Adoption refers to as the } \\
\text { implementation or use of new } \\
\text { idea or practice }\end{array}$ & $\begin{array}{l}\text { Adopt land use interventions }=1, \\
\text { Not adopt land use interventions }=0\end{array}$ \\
\hline $\begin{array}{l}\text { Institutional factors } \\
\text { e.g. PES incentives, } \\
\text { extension services, }\end{array}$ & $\begin{array}{l}\text { PES is an abbreviation of payment for } \\
\text { ecosystem services which is referred to } \\
\text { as compensation for adopting a new } \\
\text { innovation. Extension services refers to } \\
\text { as provision of farming skills to farmers }\end{array}$ & $\begin{array}{l}\text { 1) } 1 \text { if access to payment, } 0 \text { otherwise } \\
\text { 2) } 1 \text { if extension service available, } 0 \\
\text { otherwise }\end{array}$ \\
\hline $\begin{array}{l}\text { Households } \\
\text { characteristics e.g. } \\
\text { age, education level }\end{array}$ & $\begin{array}{l}\text { The influence of households' } \\
\text { characteristics in adoption of } \\
\text { innovation }\end{array}$ & $\begin{array}{l}\text { 1) Age in years } \\
\text { 2) Education level in years of } \\
\text { schooling or } 1 \text { if formal education, } \\
0 \text { otherwise }\end{array}$ \\
\hline
\end{tabular}

Salaam, Tanzania. The Uluguru Mountains altitude ranges from 300 to $2638 \mathrm{M}$ above sea level [23]. Furthermore, the ward is composed of five villages namely Nyingwa, Lanzi, Kibungo, Dimilo and Lukenge, which have similar geographical characteristics.

According to [17], about 150,000 people live in Uluguru Mountains and that they are faced by economic development where inadequate human and financial resources have led to intensive agriculture as a result there has been water pollution and land degradation [23]. It is also revealed that about $30 \%$ of the population lives on less than 1 USD per day which they supplement with subsistence farming of small plots that are managed with slash and burn practices [22]. One of the problems with this practice is that land fragmentation is extremely high and makes worse food security [22]. For example, about 2250 ha of land available in Kibungo Juu ward, approximately $86 \%$ of them owned by individual farmers do not exceed an average of 2 ha, which creates problems of land scarcity 
and food insecurity [17]. Furthermore, productivity of such small scale farming is low because of low soil fertility and financial constraints in implementing sustainable agricultural practices.

This area was selected for study because it was the place where the land use interventions were promoted under PES scheme from 2008 to 2012. The aim of the PES scheme was to manage watersheds in Uluguru Mountains as it is one of the major sources of Ruvu River which supplies water to Morogoro, Pwani and Dar es Salaam. Farmers were influenced to adopt land use interventions namely bench terraces, reforestation, agro-forestry and grass stripping farming for the purpose of managing ecosystems. According to [10] these interventions would not only protect the existence of ecosystems, particularly watersheds, but also improve crop productivity in the area.

\subsection{Research Design, Sampling Procedures, and Sample Size}

\subsubsection{Research Design}

A cross-sectional research design was employed whereby data were collected at one specific point in time. This design has a wider scope to enable incorporation of many variables at one specific time [24]. Moreover, this research design enables one to collect both qualitative and quantitative data in a short period of time and at one point in time from respondents [25] whereby this study was carried out from March 2016 to June 2016.

\subsubsection{Sample Size}

The sample size (n) was computed depending on the total number of the households $(\mathrm{N})$ in each village. According to [26], a sample size calculated between $10 \%$ and $30 \%$ of the target population is enough for a study. In this study, $20 \%$ was taken for sample calculation because of time, resources and terrain of the area. Therefore, for this study, $20 \%$ of the households formed a sample size of 219; 90 households, 69 households and 60 households came from Nyingwa, Lanzi and Lukenge villages respectively. Table 2 indicates how the sample size was obtained.

\subsubsection{Sampling Procedure}

A total of 219 households were selected randomly to participate in the interviews whereby the topics among others included household socio-economic characteristics, the types of interventions promoted in the area, what interventions were adopted, interventions not adopted at all and what hindered their uptake. Other areas were reasons to adopt or not to adopt the interventions, what incentives were promised or provided during project implementation, reasons to continue or abandon the promoted interventions after end of the project and reasons to adopt the interventions after the project implementation. Households were obtained from a list of all households in all purposively selected villages, namely Lanzi, Nyingwa and Lukenge. Only the heads of households being a male or female were invited to respond to questions from questionnaire. Purposive 
Table 2. Sample size.

\begin{tabular}{cccc}
\hline Village & Households & Sampling formula (\%) & Sample size \\
\hline Nyingwa & 454 & 20 & 90 \\
Lanzi & 345 & 20 & 69 \\
Lukenge & 302 & 20 & 60 \\
\hline
\end{tabular}

sampling was used to get key informants who included Village Executive Officers, Ward Executive Officer, and Extension Officers and members of farmer groups. Farmers' groups were formed to overcome the problem of workforce during the implementation of the promoted interventions.

\subsection{Data Collection}

Both qualitative and quantitative were gathered whereby quantitative data were collected from households using a questionnaire with both closed and open ended questions. Qualitative data were collected from FGDs and Key informant interviews whereby participants in FGDs were from specific sub-groups who had a particular knowledge on land use interventions promoted by PES scheme in the study area which included farmers, ward and village executive officers and village extension officers. These participants were obtained using a purposive sampling approach also commonly called a judgmental sampling. Two FGDs were conducted per each village whereby the number of participants involved in a FGD ranged from 7 to 8 participants.

Topics discussed during the interviews among others included the main objective of the PES project in the area, the types of interventions promoted in the area, interventions mostly adopted by farmers, interventions not adopted at all and what hindered their uptake. Other topics were reasons to adopt or not to adopt the interventions, incentives promised or provided during project implementation, benefits obtained from the project, reasons for some farmers to continue or abandon the promoted interventions after end of the project, reasons for some farmers to adopt the interventions after the project implementation.Furthermore, other topics were which practices have been abandoned and why, how can the adoption of the land use interventions be enhanced, what land use interventions should be prioritized and why? What kind of support and by whom would be required for large-scale adoption? Moreover, other questions were; how can more farmers be reached with information on promoted interventions? Any challenges you faced or suggestions for improvements?

\subsection{Data Processing and Analysis}

Content analysis was used for qualitative information whereby themes and sub-themes were summarized for interpretation based on the key concept. Quantitative data were summarized, coded and analyzed using Statistical Package for Social Sciences (SPSS) computer software whereby both descriptive and 
inferential statistical data analysis methods were used. Socio-economic characteristics of the households and adoption of land use interventions were analyzed descriptively. Socio-economic characteristics were expected to influence adoption of the interventions. Moreover, to be able to identify which land use interventions were adopted by how many households, a tallying method was used. This was possible because every household sampled was asked to mention the type of interventions adopted.

Furthermore, binary logistic regression model (Equation (1)) was used to explore the factors influencing adoption of the land use interventions. This model was employed because the adoption was measured as a dummy variable ( 1 or 0$)$ whereby (adopt $=1$ and do not adopt $=0$ ). In this study, ten independent variables and the adoption as indicated in Table 3 were fitted into the binary regression model.

$$
Y=\operatorname{In}[\mathrm{Pi} /(1-\mathrm{Pi})]=\beta_{0}+\beta_{1} x_{1 i}+\beta_{2} x_{2 i}+\cdots+\beta_{k} x_{k i}
$$

where: the subscript $i$ denotes the $i^{\text {th }}$ observation in the sample, $P$ is the probability of the outcome, $\beta_{0}$ is the intercept term and $\beta_{1}, \beta_{2}, \cdots, \beta_{k}$ are the coefficients associated with each explanatory variables $X_{1}, X_{2}, \cdots, X_{k}$. Moreover, the estimated coefficients do not directly indicate the effect of change in the corresponding explanatory variables on the probability $(\mathrm{P})$ of the outcome occurring. The coefficients reflect the effects of individual explanatory variables on the odds ratio of adoption being high or low. According to [27], the value of Nagelkerke $\mathrm{R}^{2}$ indicates the influence of independent variables entered in the model and the remaining is due to the effect caused by other factors probably not entered in the model. The Wald values demonstrated the relative contribution of individual

Table 3. Variables used in the binary logistic regression model.

\begin{tabular}{|c|c|}
\hline Variable & Definition \\
\hline \multicolumn{2}{|l|}{ Dependent variable } \\
\hline Adoption of land use interventions & 1 if adopt, $0=$ not adopt \\
\hline \multicolumn{2}{|l|}{ Independent variables } \\
\hline Sex of the household head & $1=$ Male, $0=$ Female \\
\hline Age of the household head & Age in years \\
\hline Education level of the household head & Years of schooling \\
\hline Secondary occupation of the household head & 1 if employed by formal sector, 0 otherwise \\
\hline Access to extension service & $1=\mathrm{Yes}, 0=\mathrm{No}$ \\
\hline Extra labour demand in a household & 1 if demand extra labour, 0 otherwise \\
\hline PES incentives & $\begin{array}{l}1 \text { if PES incentives necessary for adoption, } 0 \\
\text { otherwise }\end{array}$ \\
\hline Land right ownership by the household head & 1 if available, 0 otherwise \\
\hline Period of the household head to live in the same area & period in years \\
\hline Marital status of the household head & 1 if married, 0 otherwise \\
\hline
\end{tabular}


variables to the odds probability of the extent of land use interventions being adopted by the households.

\section{Results and Discussion}

\subsection{Socio-Demographic Characteristics}

Results on the socio-demographic characteristics depicted that, out of the 219 respondents, $58.9 \%$ and $41.1 \%$ were males and females respectively (Table 4 ). The results also show that majority of respondents were between 46 to 60 years of age. Moreover, $61.6 \%$ of them were married and the rest were either widow, widowers, separated or single. The majority $(49.8 \%)$ of the respondents had completed standard seven. Agriculture is the main occupation in the study area and contributes significantly to the livelihood security of the people. Out of the households, $80.8 \%$ had a secondary occupation. In addition; the majority of households had an average of 2 people who can work in the farm. Thus, socio-demographic characteristics were expected to be among variables appropriate to provide information for the objective of this study.

\subsection{Adoption of Land Use Interventions Promoted in the Study Area}

Households' survey was conducted to find out the adoption of land use interventions promoted. Results of adoption during and after the project are indicated in Table 5. The results show that 87 (40\%) out of 219 households did not implement any intervention during the project while the rest of them implemented at least one land use intervention promoted. On the other hand, results after PES scheme indicated that all households sampled had adopted at least one land use intervention while none of the households was implementing all land use interventions promoted (Table 5). This implies that some households which did not adopt any intervention during the project joined later on after learning from those who started as it was revealed during FGDs. These results do not differ greatly from those by [17] who conducted a study during the project and found that about $50 \%$ of the sample population started to practise the promoted interventions. Moreover, these results are in line with the theory of diffusion of innovation by [18], which offers theoretical analysis of qualities of innovations based on results, implying that farmers who did not enter the PES scheme in the beginning were later on attracted to practise the interventions. This is because they learnt from the early adopters as revealed from one member from Lanzi village in the FGDs who said that "I started to practise bench terrace farming after learning from others whose farming was improved".

On the other hand, some farmers argued that those who did not enter the scheme had a fear of their land to be taken away by the government. For example, these claims were given by one member from Lukenge Village who said: "In my area many people thought the government wants to take this area when they plant trees in their farms". Another member from Nyingwa Village argued that 
Table 4. Socio-demographic characteristics results $(n=219)$.

\begin{tabular}{|c|c|c|c|}
\hline Variable & category & Frequency & Percent \\
\hline \multirow[t]{3}{*}{ Age group in years } & $30-45$ & 55 & 25.1 \\
\hline & $46-60$ & 88 & 40.2 \\
\hline & $61+$ & 76 & 34.7 \\
\hline \multirow[t]{2}{*}{ Sex } & Female & 90 & 41.1 \\
\hline & Male & 129 & 58.9 \\
\hline \multirow[t]{2}{*}{ Marital status } & Unmarried & 84 & 38.4 \\
\hline & Married & 135 & 61.6 \\
\hline \multirow[t]{6}{*}{ Education level } & No formal education & 48 & 21.9 \\
\hline & Std four & 33 & 15.1 \\
\hline & std seven & 109 & 49.8 \\
\hline & std eight & 16 & 7.3 \\
\hline & Form two & 7 & 3.2 \\
\hline & Form four & 6 & 2.7 \\
\hline \multirow[t]{3}{*}{ Household workforce } & 1 & 72 & 32.9 \\
\hline & 2 & 123 & 56.2 \\
\hline & 3 & 24 & 11 \\
\hline \multirow[t]{2}{*}{ Secondary occupation } & Informal employment & 177 & 80.8 \\
\hline & Formal employment & 42 & 19.2 \\
\hline Primary occupation & Agriculture & 219 & 100.0 \\
\hline
\end{tabular}

Table 5. Adoption of land use interventions during and after the scheme $(n=219)$.

\begin{tabular}{cccccc}
\hline \multirow{2}{*}{ Number of interventions adopted } & \multicolumn{2}{c}{$\begin{array}{c}\text { Adoption during PES } \\
\text { scheme }\end{array}$} & \multicolumn{2}{c}{$\begin{array}{c}\text { Adoption after PES } \\
\text { scheme }\end{array}$} \\
\cline { 2 - 5 } & \multicolumn{2}{c}{ Frequency } & Percent & Frequency & Percent (\%) \\
\hline Did not adopt any intervention & 87 & 39.9 & 0 & 0 \\
Adopted one land use intervention & 11 & 5 & 98 & 44.7 \\
Adopted two land use interventions & 66 & 30.1 & 104 & 47.5 \\
Adopted three land use interventions & 55 & $\underline{25.1}$ & 17 & 7.8 \\
Total & 219 & $\mathbf{1 0 0}$ & 219 & 100 \\
\hline
\end{tabular}

"Due to our culture, an individual being allocated a piece of land has no rights on that land to make land modifications." However, one of the key informants added that the culture was slowly diminishing due to arrival of people from other ethnic groups. It was also revealed by one of the key informant from Lukenge Village that there are challenges facing farmers in implementing some of interventions which include shortage of organic manures, especially on bench terraces. This is in line with the theory by [19] in which one of the innovation charac- 
teristics is compatibility which may influence farmers' adoption decision. In this study, land ownership and organic manures were factors which affected adoption of the interventions particularly bench terrace construction.

Results in Table 6 show the types of land use interventions and the relative number of households per each intervention. It is indicated that few households adopted bench terrace farming after the project implementation. It was revealed that any households were able to practise interventions namely agro forestry and grass strip farming because they were not labour intensive as opposed to bench terrace construction. This was supported by results from FGDs and key informant interviews that the bench terrace farming requires more labour force than other interventions. One of the key informants from Nyingwa Village argued that during the project implementation farmers were advised to join farmer groups to be able to construct bench terraces. Furthermore, during focus group discussion, it was argued that in order to implement the interventions promoted, farmers were promised to get financial support though it was not well fulfilled. However, some farmers were provided with several incentives to facilitate implementation of interventions. Various incentives, among other things included bush knives, goats, spades, hoes, trees, crop seedlings, financial support and manure which were provided to motivate farmers. Another participant during FGDs from Lanzi village said "I was attracted to adopt the agro-forestry farming three years after the project implementation because my neighbour is getting poles for house construction and at the same time growing other crops". This situation is confirmed in the theory by [19], which proposes that relative advantage is one of the innovation characteristics which may make farmers decision to adopt or not. It is from this fact that farmers were even ready to continue implementing the interventions without being provided with incentives because the interventions alone have some benefits to farmers. This was evidenced from results that after project implementation every household was implementing the interventions at least one among the promoted interventions.

\subsection{Factors Influencing Adoption of Land Use Interventions Promoted}

Binary logistic regression model was employed to determine factors influencing adoption of land use interventions promoted by PES scheme as shown in Table 7.

Table 6. Type of land use interventions adopted during and after the project $(n=219)$.

\begin{tabular}{ccccc}
\hline $\begin{array}{c}\text { Land use } \\
\text { interventions } \\
\text { promoted }\end{array}$ & Number of HHs & $\begin{array}{c}\text { Dercentage of } \\
\text { HHs (\%) }\end{array}$ & $\begin{array}{c}\text { Number of HHs } \\
\text { Nuring the project }\end{array}$ & $\begin{array}{c}\text { Percentage of } \\
\text { HHs (\%) }\end{array}$ \\
\hline Bench terraces & 88 & 40 & 60 & 27 \\
Agro-forestry & 57 & 26 & 84 & 38 \\
Reforestation & 78 & 36 & 136 & 62 \\
Grass strip farming & 95 & 43 & 160 & 73 \\
\hline
\end{tabular}


Table 7. Binary logistic regression results for factors influencing adoption of land use interventions.

\begin{tabular}{|c|c|c|c|c|c|c|c|c|}
\hline \multirow{2}{*}{ Variables } & \multirow{2}{*}{ B } & \multirow{2}{*}{ S.E. } & \multirow{2}{*}{ Wald } & \multirow{2}{*}{$\mathrm{df}$} & \multirow{2}{*}{ Sig. } & \multirow{2}{*}{$\operatorname{Exp}(B)$} & \multicolumn{2}{|c|}{ 95\% C.I. for $\operatorname{EXP}(B)$} \\
\hline & & & & & & & Lower & Upper \\
\hline Age of $\mathrm{HHH}$ & -0.070 & 0.026 & 7.294 & 1 & 0.007 & 0.932 & 0.886 & 0.981 \\
\hline $\begin{array}{c}\text { Education level of } \\
\text { HHH }\end{array}$ & -0.244 & 0.100 & 5.967 & 1 & 0.015 & 0.784 & 0.644 & 0.953 \\
\hline $\begin{array}{c}\text { Secondary } \\
\text { occupation of } \mathrm{HHH}\end{array}$ & 0.300 & 0.622 & 0.232 & 1 & 0.630 & 1.349 & 0.399 & 4.563 \\
\hline $\begin{array}{c}\text { Land ownership of } \\
\text { HHH }\end{array}$ & 4.788 & 0.787 & 37.000 & 1 & 0.000 & 120.065 & 25.668 & 561.607 \\
\hline Extra labour & 2.442 & 1.127 & 4.690 & 1 & 0.030 & 11.493 & 1.261 & 104.749 \\
\hline Extension service & 1.216 & 0.502 & 5.858 & 1 & 0.016 & 3.373 & 1.260 & 9.029 \\
\hline Marital status $\mathrm{HHH}$ & -0.606 & 0.639 & 0.900 & 1 & 0.343 & 0.545 & 0.156 & 1.909 \\
\hline PES incentives & -1.276 & 0.493 & 6.690 & 1 & 0.010 & 0.279 & 0.106 & 0.734 \\
\hline Sex of HHH & -0.115 & 0.624 & 0.034 & 1 & 0.854 & 0.892 & 0.263 & 3.028 \\
\hline $\begin{array}{l}\text { Years of living in } \\
\text { the same area }\end{array}$ & -0.138 & 0.034 & 16.680 & 1 & 0.000 & 0.871 & 0.816 & 0.931 \\
\hline Constant & 5.912 & 2.829 & 4.368 & 1 & 0.037 & 369.598 & & \\
\hline
\end{tabular}

Note: Variables significant at 0.05 , Omnibus Test of model Coefficient (Chi-square $=177.817, \mathrm{p}=0.000$ ), Nagelkerke Pseudo- $\mathrm{R}^{2}=0.744$.

The model revealed that out of ten variables entered in the model, seven (age of the household head, access to extension service, education level of the household head, extra labour, years of living in the same area, payment and the land right ownership by the household head) were found to influence the adoption at ( $\mathrm{p} \leq$ $0.05)$. Whereby the strongest predictor was availability of land right ownership at $(p=0.000)$. Furthermore, it was found that generally the $p$-value was statistically significant implying the model fitness for all predictors entered (Chi-Square $=177.817, \mathrm{p}=0.000, \mathrm{df}=10$ ). These results prove that application of the model was appropriate for predicting the adoption in this study. Moreover, results show that Nagelkerke $\mathrm{R}^{2}$ was 0.744 suggesting that $74.4 \%$ of the variance in the adoption was explained by the factors entered in the model. The remaining $25.6 \%$ probably due to other factors not included in the model.

The influence of land ownership right on adoption of land use interventions, as indicated in Table 7 , was found to be statistically significant $(\mathrm{p}=0.000)$ and $\operatorname{Exp}(B)=120.065$. This implies that farmers with land ownership right were likely to increase adoption of land use interventions as compared to those without land right ownership in the study area. This means if possession of land ownership increased by one unit, the adoption of interventions increased by 4.788 units as indicated by the odds ratio that was 120.065 . Implying that land ownership right was 4.788 times more likely to contribute to adoption. This is also supported by [28] who found that land tenure determines the type of farming system and farmers ability to invest in natural resource management meas- 
ures. However, this is contrary with results from [29] who found that possession of land under traditional land tenure such as matrilineal inheritance in most parts of the Uluguru mountains were likely to decrease the adoption of land use interventions because such household head has no absolute land ownership rights to make long-term investment on the land.

Access to extension services was also found to influence the adoption of land use interventions and statistically significant at $(\mathrm{p}=0.016)$ and $\operatorname{Exp}(\mathrm{B})=3.373$ (Table 7). This implies that access to extension services to the farmers increased the probability of adoption. It was also indicated that if the access to extension services was increased by one unit then the adoption of interventions would increase by 1.216 units as indicated by the odds ratio that was 3.373 This means that farmers with access to extension services were 1.216 times more likely to adopt many interventions, that is as farmers get more extension services, there is a possibility to have farmers adopting varieties of interventions. This was also revealed from one of the key informants who said that during the project implementation farmers had an opportunity to get extension services on how to implement the promoted interventions and this made most of them to adopt many interventions. Moreover during one of the FGDs, a participant from Lukenge village said "due to PES scheme project implementation, I was always visited by extension officers and this encouraged me to adopt many interventions".

Furthermore, results reveal that age of the household head in adoption of land use interventions as indicated in Table 7 was found to be statistically significant but negatively influencing the adoption $(p=0.007)$ and $\operatorname{Exp}(B)=0.932$. This implies that age of the household head decreased the probability of adoption of the interventions. It was also indicated that if the age of the household head increased by one unit adoption would decrease by 0.07 units as indicated by the odds ratio of 0.932 . This means that household heads with older age were 0.07 times less likely to contribute to decrease in adoption. Results show that households with a higher number of older household heads are less likely to adopt new farming technologies. This was also pointed out by one member from Lanzi village during one of the FGDs that "Farmers with younger age had a good chance to implement the interventions promoted such as bench terrace farming". These results are supported by a similar study by [30] who argued that, compared to younger employees; older workers are less likely to use new technologies. This implies that as the age increases, the ability of the farmer to engage in farm works decreases, especially when workforce is to be provided by him or her. However, these results differ from that of [31] who found that age was positively influencing adoption of sorghum in Burkina Faso.

Moreover, education level of the household head was found to be statistically significant $(\mathrm{p}=0.015)$ and $\operatorname{Exp}(\mathrm{B})=0.784$. This implies that household head with higher education level had low probability of adopting the promoted interventions. It was also indicated that if the household head has higher education 
level, the adoption would decrease by 0.244 as indicated by the odds ratio of 0.784 . This means that household heads with higher education level were 0.244 times less likely to adopt interventions. This was supported many participants from the FGDs who said household heads with higher education level do not engage themselves in farming activities. For example one member from Lanzi said "In our village farming activities are done by people with low level of education because farmers with higher levels of education such as college level are doing other occupation". This implies that as long as the promoted interventions were associated with farming, few household heads with higher level adopted the intervention. However, [32] argued that education is a necessary but not sufficient condition for an individual to enjoy good labour market outcomes. This means that there is no significant clear relationship between educational achievement and occupation factor across the world.

Moreover, extra labour demand was found to be statistically significant ( $\mathrm{p}=$ $0.03)$ and $\operatorname{Exp}(B)=11.494$. This implies that extra labour increase the probability of adoption. It was also indicated that if the household had enough labour force, the adoption would increase by 2.442 as indicated by the odds ratio of 11.494. This means that households with more labour force were 2.442 times more likely to adopt interventions especially labour intensive ones such as construction of bench terraces. Results from FGDs revealed that more labour force was required to implement some interventions which are labour force demand, for example one farmer from Nyingwa village said "In my household, I don't have enough labour force to construct bench terraces unless I get more from outside". Majority of households have an average of 2 people who can work in the farms, a situation which makes difficult to implement some of the proposed interventions such as bench terraces. In this case, every household is obliged to hire extra labour forces because in order to construct one bench terrace of size $20 \mathrm{~m} \times 5 \mathrm{~m}$, a minimum of $10 \mathrm{to} 15$ workforce size is needed as revealed by one the key informants in the study area.

It was further revealed that, payment as incentives to farmers was statistically significant $(\mathrm{p}=0.01)$ and $\operatorname{Exp}(\mathrm{B})=0.279$. This implies that payments influenced more adoption of the interventions. It was also indicated that if the household had not received payment, the adoption would decrease by 1.276 as indicated by the odds ratio of 0.279 . This means that household heads who received PES incentives were 1.276 times more likely to adopt interventions. It was supported by results from FGDs as one of the participants from Lukenge village said " $I$ was very much attracted to enter into the project when I heard that we are going to get incentives such as money, spades, bush knives and hoes". On the other hand a participant from Lanzi village said "I did not adopt the interventions because of lack of Farming tools such as hoes and bush knives". These results are in line with a study by [33] who argues that in order for farmers to adopt agricultural conservation practices an initial dose of state (incentives) is needed. They further add that the farms benefiting from the government conservation programme 
have done better than those not involved.

In addition, results show that years of living in the same area was found to be statistically significant $(\mathrm{p}=0.000)$ and $\operatorname{Exp}(\mathrm{B})=0.871$. This implies that duration of the farmer to live in the same area influence the probability of adoption of the interventions. It was indicated that if the household had many years of living in the same area, the adoption would decrease by 0.138 as indicated by the odds ratio of 0.871 . This means the number of years of the household head was 0.138 times less likely to contribute to adoption of land use interventions. Many household heads especially who have been in the same area for many years were reluctant to change their agricultural practices. This was revealed from the interview with one of the key informants from Nyingwa village who said that household heads who have lived for many years at the same area, it was not easy to convince them to adopt land use interventions particularly the bench terrace construction. The results from FGDs as revealed by one of the participants who was born and lived at Nyingwa village said that "I have been cultivating on Uluguru Mountains and obtain crops which are enough for my family, so you cannot convince me to use bench terraces". These results are in line with [17] who revealed that the number of years of a household head to live in the same village (area) is likely to influence the adoption. As the number of years increase, the adoption becomes less because farmers with this situation are more reluctant to change unless they are motivated.

The non-significance of the coefficients for sex, marital status and secondary occupation is probably because the availability of incentives, extension services and land ownership would serve as the basic motivating factors for adoption of the land use interventions.

\section{Conclusions and Recommendations}

This study aimed at assessing the adoption of land use interventions promoted by PES initiatives in Uluguru Mountains in Tanzania. Results showed that adoption was high after PES project had phased out because every household sampled had adopted the land use interventions while during the project implementation; it was low as not all households sampled had adopted the interventions. Furthermore, age, extension services, work force, PES incentives, years of living in the same area, education level of the household head and land right ownership were found to influence adoption of the interventions.

Therefore, households' characteristics and institutional factors influence adoption of land use interventions promoted by PES. Thus these results emphasize the importance of focusing on households' characteristics and institutional factors, such as farmers' access to extension services and incentives as components in influencing adoption of innovations. For example adoption of land use interventions particularly agro-forestry and bench terraces construction in Uluguru Mountains can be realized if ownership of land is taken into account.

Therefore, development practitioners should support farmers by focusing on 
the nature of households' socio-economic characteristics to enable them adopt newly introduced interventions. Furthermore, the government should facilitate farmers with extension services and incentives because they have important implications in terms of adoption of different innovations, especially those associated with farming. Moreover, farmers should be educated and encouraged to join farmers' groups to solve the problem of labour force, especially when it is provided by the farmers themselves.

\section{References}

[1] Wunder, S., Engel, S. and Pagiola, S. (2008) Taking Stock: A Comparative Analysis of Payments for Environmental Services Programs in Developed and Developing Countries. Ecological Economics, 65, 834-852. https://doi.org/10.1016/j.ecolecon.2008.03.010

[2] Wunsher, T., Engel, S. and Wunder, S. (2008) Spatial Targeting of Payments for Environmental Services; a tool for Boosting Conservation Benefits. Ecological Economics, 65, 822-833. https://doi.org/10.1016/j.ecolecon.2007.11.014

[3] Miles, L. and Kapos, V. (2008) Reducing Greenhouse Gas Emissions from Deforestation and Forest Degradation: Global Land-Use Implications. Science, 320, 1454-1455. https://doi.org/10.1126/science.1155358

[4] Malimbwi, R.E. (2002) Forest Extent and Ownership in Tanzania. Consultancy Report, Tanzania Conservation and Management Project Forestry and Beekeeping Division, Dar es Salaam.

[5] Kiss, A. (2004) Making Biodiversity Conservation a Land Use Priority. In: Mcshane, T. and Wells, M., Getting Biodiversity Project Work: Towards More Effective Conservation \& Development, Columbia University Press, New York. https://doi.org/10.7312/mcsh12764-008

[6] Engel, S., Pagiola, S. and Wunder, S. (2008) Designing Payments for Environmental Services in Theory and Practice: An Overview of the Issues. Ecological Economics, 65, 663-674. https://doi.org/10.1016/j.ecolecon.2008.03.011

[7] Waage, S., Scherr, S., Jenkins, M. and Inbar, M. (2006) A Scoping Assessment of Current Work on Payments for Ecosystem Services in Asia. Forest Trends, Washington DC.

[8] Wunder, S. (2005) Payment for Ecosystem Service; Nuts and Bolts. Center for International Forestry Research Occasional Paper No. 42, Jakarta.

[9] Kabudi, P.J. (2005) Challenges of Legislating from Water Utilization in Rural Tanzania: Drafting New Laws. The International Workshop on African Water Laws: Plural Legislative Frameworks for Rural Water Management in Africa, Johannesburg, 26-28 January 2005.

[10] CARE and WWF (2008) Household Survey Conducted in Kibungo Sub-Catchments. EPWS Phase II. CARE International in Tanzania and World Wide Fund for Nature in Tanzania, Dar es Salaam.

[11] Muller, J. and Albers, H.J. (2004) Enforcement, Payments, and Development Projects near Protected Areas: How the Market Setting Determines What Works Where. Resource and Energy Economics, 26, 185-204. https://doi.org/10.1016/j.reseneeco.2003.11.007

[12] Pagiola, S., Rios, A. and Arcenas, A. (2008) Can the Poor Participate in Payments for Environmental Services? Lessons from the Silvopastoral Project in Nicaragua, 
Environment and Development Economics, 13, 299-325. https://doi.org/10.1017/S1355770X08004270

[13] Ferraro, P.J. (2009) Regional Review of Payments for Watershed Services: Sub Saharan Africa. Journal of Sustainable Forestry, 28, 525-550. https://doi.org/10.1080/10549810802701234

[14] Wunder, S. (2007) The Efficiency of Payment for Environmental Services in Tropical Conservation. Conservation Biology, 21, 48-58. https://doi.org/10.1111/j.1523-1739.2006.00559.x

[15] Mombo, F.M. (2013) A New Institutional Economics Approach to Evaluate Management Options for Wetlands: The Case of Kilombero Valley Wetlands in Tanzania. Doctoral Thesis, Ghent University, Ghent

[16] CARE and WWF (2009) Equitable Payments for Watershed Services in the Uluguru Mountains in Tanzania: Making Progress on Slippery Slopes.

[17] John, I. (2012) How Successful Has Payment for Environmental Services Improved Welfare? Dissertation for Award of MA Degree, University of Dar es Salaam, Tanzania.

[18] Rogers, M.E. (2003) Diffusion of Innovations. Fifth Edition, Free Press, New York, $221 \mathrm{p}$.

[19] Rogers, E.M. (1995) Diffusion of Innovations. Free Press, New York.

[20] Rogers, E.M., Medina, U.E., Rivera, M.A. and Wiley, M.A. (2005) Complex Adaptive Systems and the Diffusion of Innovations. The Innovation Journal: The Public Sector Innovation Journal, 10, Article 30.

[21] Rijn, F., Bulte, E. and Adekunle, A. (2012) Social Capital and Agricultural Innovation in Sub Saharan Africa. Agricultural Systems, 108, 112-122.

[22] The United Republic of Tanzania (2005) Ministry of Natural Resources and Tourism: Conservation and Management of the Eastern Arc Mountain Forests, Tanzania. Uluguru Component Biodiversity Survey 2005 (Volume III) Uluguru North Forest Reserve. GEF-UNDP: URT/01/G32. Prepared by Frontier-Tanzania, Dar es Salaam.

[23] CARE and WWF (2007) Equitable Payments for Watershed Services-Feasibility Study Methodology. A Business Case Approach. The Capacity-Building Workshop on the Role of Payments for Environmental Services (PES), Dar es Salaam.

[24] Walliman, N. (2006) Social Research Methods. Sage Publications, London and Thousand Oaks, New Delhi, 224 p. https://doi.org/10.4135/9781849209939

[25] Bailey, D.K. (1998) Methods of Social Research. Collier Macmillan Publishers, London, $478 \mathrm{p}$.

[26] Mugenda, M.O. and Mugenda, G.A. (2003) Research Methods: Quantitative and Qualitative Approaches. African Centre for Technology Studies, Nairobi.

[27] Mendenhall, W. and Beaver, R.J. (1991) Introduction to Probability and Statistics. 14th Edition, Richard Stratton Publishers, Boston.

[28] Hella, J.P. (2003) Economic Analysis of the Relationship between Smallholder Farming Strategies and Soil Degradation in Semi-Arid Tanzania. Thesis for Award of PhD Degree at Gent University, Gent, 277 p.

[29] Young, R. and Fosbrooke, H. (1960) Smoke in the Hills. Political Tension in the Morogoro District of Tanganyika. North-Western University Press, Evanston, 783 p.

[30] Koch, A. and Strotmann, H. (2006) Determinants of Innovative Activity in Newly 
Founded Knowledge Intensive Business Service Firms. In: Fritsch, M. and Schmude, J. Eds., Entrepreneurship in the Region, Vol. 14 of International Studies in Entrepreneurship, Springer-Verlag, Berlin.

[31] Adesiina, A.A. and Baidu-Forson, J. (1995) Farmers' Perceptions and Adoption of New Agricultural Technology: Evidence from Analysis in Burkina Faso and Guinea, West Africa. Journal of Agricultural Economics, 13, 1-9.

[32] Khamis, F.G., Hanoon, M.F. and Belarbi, A. (2010) The Relationship between Education and Occupation Using Fully and Partially Latent Models. International Journal of Intelligent Technologies and applied Statistics, 3, 309-322.

[33] Pande, V.C., Kurothe, R.S., Singh, H.B. and Tiwari, S.P. (2011) Incentives for Soil and Water Conservation on Farm in Ravines of Gujarat: Policy Implications for Future Adoption. Agricultural Economics Research Review, 24, 109-118. 